\title{
Institutional bricolage in times of crisis
}

\author{
MARTIN B. CARSTENSEN* \\ Department of Business and Politics, Copenhagen Business School, Denmark
}

\begin{abstract}
How may we understand the occurrence of gradual but significant change following economic crisis? Theories of gradual institutional transformation offer important insights to analyses of long-term institutional change, but have so far shied away from dealing with institutional change during and following crisis, leaving the issue to more traditional critical juncture models. Instead of seeing gradual institutional change originating only in the efforts of rule takers to circumvent existing institutions - potentially leading to gradual change over longer periods of time - the paper suggests that in more abrupt processes of change characteristic of economic crisis, rule makers may also reinterpret the meaning of rules and redeploy them under significantly altered circumstances leading to gradual change. The paper suggests that the concept of bricolage is useful for understanding how policymakers create new institutional setups through the re-ordering of existing institutional elements. The empirical relevance of these arguments is demonstrated with a study of post-crisis special bank insolvency policies in Denmark and the United States, showing how in both polities new institutions were created from existing institutional elements.
\end{abstract}

Keywords: institutional change; gradual transformation; bricolage; crisis; financial regulation

\section{Introduction}

The financial and economic crisis of 2007-2010 dealt a blow to the ideational and institutional structures of advanced financial capitalism, and its ramifications continue to ripple through the world economy. With policymakers scrambling to address these challenges, resulting in institutional and ideational change in a host of policy areas, one could expect historical institutionalist theories that use notions of critical junctures and paradigm shifts to feature prominently among current accounts of institutional change in wake of the crisis. So far, however, in areas like financial regulation and economic governance, scholars are finding signs of significant gradual change rather than the paradigmatic shifts hypothesized by classic historical institutionalist theory (see e.g. Bermeo and Pontussen, 2012; Moschella and Tsingou, 2013; Schmidt and Thatcher, 2013; Helleiner, 2014; Baker, 2015). Somewhat surprisingly then, the crisis turns out to provide ample opportunity to use and further develop what this paper terms the gradualist approach to institutional change, that is, the growing literature on cumulative institutional change that perhaps most concisely found expression in Streeck and Thelen (2005), was further

* E-mail: mbc.dbp@cbs.dk 
developed in Mahoney and Thelen (2010) and used in a large number of studies in comparative political economy (notably Crouch, 2005; Djelic and Quack, 2007; Schneiberg, 2007; Deeg and Jackson, 2012). Unfortunately, a self-inflicted analytical limitation is hampering the potential of gradual institutionalist analysis by leaving explanations of institutional change during and after crisis to more traditional historical institutionalist approaches. Thus, with the argument that the significant changes that often follow crises and critical junctures are already sufficiently dealt with in the existing institutionalist literature, the pivotal contributions of Streeck and Thelen (2005) and Mahoney and Thelen (2010) refrain from dealing with the central issue of how new institutional configurations come about in the wake of a crisis.

This paper is a first stab at showing the relevance of gradualist theories for understanding institutional change during periods of crisis. The argument is developed through a refocusing of Streeck and Thelen's (2005) and Mahoney and Thelen's (2010) emphasis on the relation between rule makers and rule takers within an extended time frame. Instead of seeing gradual institutional change originating only in the efforts of rule takers to circumvent existing institutions - potentially leading to gradual change over longer periods of time - this paper suggests that in more abrupt processes of change, characteristic of an economic crisis, rule makers may also reinterpret the meaning of rules and redeploy them under significantly altered circumstances. In this perspective, change during crisis does not primarily come from a lack of enforcement on part of rule makers and strategic non-compliance by rule takers, but from policymakers' efforts to reinterpret what an institution can mean under changed circumstances and which novel institutional elements can potentially be added to the institutional mix to respond to crisis. Moreover, the paper argues that following a crisis, new institutions are often created as bricolages of existing and sometimes also new institutional elements (see Campbell, 2004; Carstensen, 2011; Clift, 2012). In this view, policymakers respond to circumstances of uncertainty and crisis with rearrangement and redeployment of existing institutional elements. Given that existing institutions were crafted to work under significantly different circumstances, institutional bricolage in a period of crisis requires active and often pragmatic work on part of policymakers to re-apply the existing logic of action, that is the strategies, routine approaches, and shared decision rules that structure interaction in the institutional setup (Deeg, 2005). The paper suggests that the logic of action in a policy area may change gradually, albeit significantly, during a crisis. This may occur either 'organically' from rule makers' application of existing institutions under novel circumstances (limited bricolage) - similar to what Streeck and Thelen (2005) refer to as institutional conversion - or when policymakers graft institutional elements representing a different logic of action on to the existing institutional setup (expansive bricolage), which may be thought of in terms of a layering of new institutional elements onto the existing setup.

The paper exemplifies the two forms of gradual change during a crisis by analyzing the creation of special bank insolvency policies in the United States and 
Denmark in wake of the recent financial crisis. In both cases, it is demonstrated that in crafting new institutions to resolve failing banks, policymakers first resorted to re-application of the existing logic of action under novel circumstances that were then continually adjusted, leading to a gradual change in the logic of action governing bank resolution policies in the two economies. The Danish case is characterized by limited bricolage, since the existing logic of action governing crisis management developed through the banking crisis of the 1980s and 1990s was used and continually developed throughout the crisis. The American case, on the other hand, is best understood as an instance of expansive bricolage, where the Obama administration tried to institutionalize the existing logic of action but given strong resistance in Congress towards policies that could be framed as supporting the practice of bailout, it was necessary to bring in a more 'rule based' logic of action aimed at limiting regulatory discretion - a logic of action found in existing institutions for resolution of non-systemic financial institutions.

\section{Crisis, gradual change, and bricolage}

When Streeck and Thelen (2005) published their seminal introductory chapter on gradual institutional change in advanced political economies, it formed an answer to a critique of historical institutionalist theorizing of change dynamics that in preceding years had been aired with increasing intensity. Critics charged that despite the success historical institutionalism was enjoying in explaining institutional stability, the tradition did not perform as well in accounting for change (Campbell, 2004; Streeck and Thelen, 2005: 7; Djelic and Quack, 2007: 164; Schmidt, 2009). To counter the conservative bias in the existing institutionalist literature, the authors sought to supplement theories of path dependency with a notion of significant gradual transformation. This was not to argue that institutional change is never abrupt and sharp but rather to point out that this might not be the only, and not even the most important, mode of institutional change.

Of particular importance was Streeck and Thelen's (2005: 11) emphasis on enforcement and compliance as interpretative processes by which institutions are translated into behavior. The gradualists thus made room for incremental changes in institutional analysis by pointing out how the enactment of a social rule is never perfect, and that there always remains a gap between the ideal pattern of a rule and the real pattern of life under it (Mahoney and Thelen, 2010: 10). Because applying a rule to a specific situation is a creative act that must take into account not just the rule itself, but also the unique circumstances to which it is to be applied (Streeck and Thelen, 2005: 14), the practice of rule enactment opens up avenues for political actors to bring about change through strategic non-compliance through novel interpretations of existing rules.

Despite the significant merit of the gradualist approach, it does not answer a central question, namely how we may account for institutional change following a 
Table 1. Types of institutional change: processes and results

\begin{tabular}{lll}
\hline \hline & \multicolumn{2}{c}{ Result of change } \\
\cline { 2 - 3 } & Continuity & Discontinuity \\
\hline $\begin{array}{l}\text { Process of change } \\
\text { Incremental }\end{array}$ & $\begin{array}{l}\text { Reproduction by } \\
\text { adaptation }\end{array}$ & $\begin{array}{l}\text { The gradualists } \\
\text { Gradual transformation, for example, } \\
\text { layering, conversion and replacement } \\
\text { Classic punctuated equilibrium models } \\
\text { Bbrupt }\end{array}$ \\
\hline \hline
\end{tabular}

Adapted from Streeck and Thelen (2005: 9).

crisis. Instead, the ambition of the gradualists has so far remained to conceptualize and emphasize the centrality of gradual forms of change over long stretches of time:

We have good theories of why various kinds of basic institutional configurations ... come into being ... And we have theories to explain those crucial moments when these institutional configurations are upended and replaced with fundamentally new ones. But still lacking are equally useful tools for explaining the more gradual evolution of institutions once they have been established (Mahoney and Thelen, 2010: 2).

The claim is that the exogenous shocks or environmental shifts of classic punctuated equilibrium models of change (lower right corner of Table 1) can account for the genesis of institutions during critical junctures, while more attention should be paid to gradual change (upper right corner of Table 1) to cover the whole pallet of relevant forms of institutional change. This is analogous to the conceptualization of critical junctures by Capoccia and Kelemen (2007) and Soifer (2012) that recognize both institutional change and continuity following a critical juncture as potential outcomes, but do not allow for the possibility that a crisis may also lead to gradual change.

Particularly important for adjusting the gradualist approach to analyzing institutional change following a crisis is to redress its understanding of actors' interpretation of existing institutions. Streeck and Thelen's (2005) original statement emphasized the interpretive work of actors that goes into actual institutional practice. By distinguishing, on one hand, between rule makers and rule takers, and, on the other, between rules and their enactment, Streeck and Thelen opened the possibility 'that institutional change may be generated as a result of the normal, everyday implementation and enactment of institutions' (2005: 11, emphasis in original). While the gradualists focus on the necessary under-specification of rules, and the ability that this offers strategic agency to gradually circumvent and change institutions, in the context of institutional change in times of crisis, we are interested in a different sort of interpretive process. Here it is rule makers that have to reinterpret and redeploy rules in light of significantly changed circumstances and often 
under severe time pressure. The inherent openness of institutions means that rules that might have been developed in one context - potentially a period of general stability - can turn out to be relevant and useful in a very different context of crisis if reworked and redeployed. In a context of crisis, then, agency is less about strategically and slowly circumventing institutions, and more about fast decision making based on reinterpretations of what policy problems the existing institutional setup can be directed at. Rarely is this a straightforward and unproblematic application of existing rules in a new context, because significant work goes into adjusting the rules to make them work in a different context. For example, in the cases analyzed in this paper - the crafting of special bank insolvency policies in Denmark and the United States - new institutions were created, but they were established through a complex process of reinterpretation and reuse of existing institutions under significantly altered circumstances.

The above argument that institutions are characterized by interpretive openness and room for 'play' not only for rule takers, but also for rule makers, emphasizes how during times of crisis, new institutions may be created and institutional reconfigurations enacted from interpretations and practices related to the existing order. This resembles what other authors from the gradualist approach have referred to as 'bricolage' (e.g. Campbell, 2004; Djelic and Quack, 2007; Schneiberg, 2007; Carstensen, 2011, 2013; Clift, 2012), that is, the redeployment of existing institutional elements to solve new problems. ${ }^{1}$ The concept of the bricoleur was first developed in the work of the French anthropologist Claude Levi-Strauss, and may be thought of as 'someone who works with his hands and uses devious means compared to those of a craftsman' (1962: 16-17). Unlike the scientist - in Levi-Strauss' terms, the ideal-typical counterpart to the bricoleur - who picks his instruments based on the project at hand, the bricoleur picks from a finite set of heterogeneous tools that bear no relation to the current project. The usefulness of the instruments is not defined by a project, but from the practice of making do with 'whatever is at hand' (Levi-Strauss, 1962: 17-18, see Carstensen, 2015).

Bricolage is also relevant for understanding processes of institutional change. In this perspective, institutions provide a repertoire of already existing institutional principles and practices that actors can use to innovate. In the words of Campbell (2004: 72), 'institutions provide the tool kit or repertoire with which actors modify institutions'. This is similar to the focus on how actors and organizations pragmatically handle uncertainty and complexity represented by the research traditions on 'disjointed incrementalism' (March and Simon, 1958; Lindblom, 1959; Lustick, 1980) and 'problemistic search' (Cyert and March 1963), where actors look to

\footnotetext{
1 The notion that institutions are composite, more or less fragmented 'patchworks', established through the political struggle for power and legitimacy and actors' continual interpretation of institutions, is a perspective on institutional change and stability that also finds support in the historical institutionalist study of American political development (an early notable example being Skowronek, 1982). My thanks to a reviewer for pointing this out to me.
} 
current analogies that can be extended or developed appropriately. The result is not just a reproduction of the existing institutions, as in the traditional path dependency model, but rather significant gradual change. In this vein, authors have argued for a more change-oriented and less structuralist approach to bricolage than the one first developed by Levi-Strauss. In this perspective, bricolage is not only about the reuse of existing institutional elements, but also - resembling the process of mimetic isomorphism discussed by DiMaggio and Powell (1983) - about the transfer of practices from one field to another in which they have not previously been applied, leading to true innovation (Crouch, 2005: 88). This potentially makes the process more creative by analytically granting actors access to new institutional and ideational elements (Campbell, 2004).

Often bricolage will also be prevalent during a period of crisis. Decision making in moments of relative structural indeterminism - that is, critical junctures - is characterized by uncertainty (Capoccia and Kelemen, 2007: 354; Soifer, 2012), typically resembling situations of crisis, meaning that actors cannot use standard operating procedures to solve the problems they are faced with (Beckert, 1999; Blyth, 2002). To act despite this uncertainty, agents need creatively to 'act back' upon the environment in purposive ways (Blyth, 2010: 97), and since they have no standard solution to turn to, actors have to make up new solutions as they go along. Put differently, actors move outwards basing new solutions on their experience of the world before the crisis hit. This is also the argument of Beckert (1999), when he notes how new strategies and institutions do not come out of the blue. Instead, new strategies take shape based on a reinterpretation and redeployment of existing institutions, because 'the strategies for better outcomes are only recognizable due to the reduction of uncertainty achieved through the institutional structure already in place' (Beckert, 1999: 784).

Allowing for the possibility of institutional bricolage as a potential outcome of a crisis, begs the question how we may distinguish it from other forms of change, specifically basic continuity and a radical shift in an institutional setup, respectively. Here we may draw on Deeg (2005), who suggests we think of institutions as governed by a certain 'logic of action', or - given that institutional fields can be quite heterogeneously structured - by multiple logics of action. He defines a logic of action as the typical strategies, routine approaches to problems, and shared decision rules that produce predictable patterns of behavior by actors within the system' (Deeg, 2005: 172, emphasis in original). In this view, we may witness the introduction of one or even several new institutions - understood as 'a set of rules stipulating expected behavior and "ruling out" behavior deemed undesirable (Streeck and Thelen, 2005: 12-13) - without necessarily seeing a radical institutional change. What matters is what 'logic of action' agents have at their disposal when they enact rules in novel situations. The gradualist approach has so far tended to use the concept of a 'logic of action' on a macro level, specifically to characterize national political economies according to how liberal or 'organized' they are (Etienne and Schnyder, 2014). In the context of this paper, 'logic of action' 
is used on a more specific policy level to signify a 'meta-rule' governing the interpretation of a given structure of rules within a policy area. Harking back to this paper's refocusing of the gradualist approach to deal with rule makers' redeployment of existing institutions, in this case, it is not rule takers who seek to circumvent the logic of action that structures interaction within a policy area, but instead rule makers who try to redeploy the logic of action to new purposes to shore up the existing institutional setup.

If we follow Streeck and Thelen (2005) and Deeg's (2005) focus on logics of action as the metric for institutional change, the degree of change that result from this kind of process depends on how much the logic of action within the policy area changes as a result of its redeployment under novel circumstances. If, in spite of a situation of economic crisis, policymakers are able to directly apply the existing institutional meta rule of a policy area under the novel circumstances brought on by the crisis, or craft new institutions without adjusting the existing logic of action, this will signify a 'survival and return' of the institutional setup. On the other end of the continuum, we might imagine that a crisis brings on a wholesale change in logic of action typical of punctuated equilibrium-style change leading to the introduction of a new set of routine approaches and strategies within the policy field. A more gradual form may also be the result if policymakers create new institutions based on the pre-crisis logic of action, but in the process of redeployment the logic of action undergoes a gradual change. This may happen organically and without the introduction of institutional elements representing a different logic of action to the institutional field. In such a process of gradual change following a crisis - what we may term an instance of 'limited bricolage' - the changes occurring in the institutional logic of action come from the reuse of existing institutional elements under significantly changed circumstances.

One example of such a process is found in the analysis of the Danish case below. The authorities' application of a logic of action developed during the Danish banking crisis of the 1980s - specifically that the banking sector collectively funds resolutions of failing banks, and that the state acts as a broker of mergers without taking ownership in banks - developed through a process of trial-and-error into a model for bank resolution, where the state takes a more hands-on approach in selling a failing bank to another bank, either by offering a dowry to the acquiring bank or by selling healthy assets and resolving toxic assets itself, funding it through a dowry paid by the banking sector. By trying to use the pre-crisis logic of action, specifically regarding the role of the Danish state as a mediator in crisis management, policymakers ended up with a reinterpreted logic of action, leading to the crafting of new institutions for bank resolution.

Gradual change in an institutional field may also happen when the logic of action governing actors' interpretation of institutions are supplemented with - but not fully replaced by - institutional elements from a different logic of action. This we may term 'expansive bricolage'. In instances of expansive bricolage, policymakers graft one or more new institutional elements that represent a different logic of action 
than the one characterizing pre-crisis times onto the existing institutional ensemble. It matters less for the degree of change how many new institutional elements are added to an institutional field. More important is whether actors use existing institutions following a different logic of action as well as whether institutions representing a different logic of action are added to the mix. As shown in the following section, the American case of crafting special bank insolvency policies in wake of the crisis offers us an example of expansive bricolage. As part of the major regulatory overhaul following the financial crisis, the Obama administration first tried to create a new set of institutions relating to the resolution of systemically important financial institutions (SIFI) based on the logic of action that had governed the management of failing financial institutions before and during the crisis. This involved granting authorities greater powers and discretion in intervening in financial institutions before the point of insolvency. However, as regulators like the FDIC along with Democratic and Republican members of Congress continually criticized the leeway for conducting bailouts that the new legislation created, for the resolution authority to gain traction in House and Senate it turned out to be necessary to add institutional elements drawing on a different logic of action, specifically clearer limits on the discretion of the authorities, including a requirement for liquidation.

To illustrate how the causal mechanism of institutional bricolage works in times of crisis, the following section presents a case study of how Danish and American policymakers responded to the financial crisis by crafting a new set of institutions for resolving failing financial institutions. Studying these two cases lends insights to how institutional bricolage works across two different institutional contexts. That is, on one hand, the case study shows that despite their differences in terms of political system and tradition for handling of banking crises, in both cases policymakers responded to the crisis by seeking to extend the existing logic of action to answer to new circumstances. The case study thus shows that institutional bricolage occured in two quite different political systems: an American system characterized by a high degree of politicization and conflict, and a Danish political system where crisis management was characterized by quite strong consensus and, to a large degree, left to civil servants. Second, despite the similarities in outcome across the two systems, the comparison of the American and Danish cases is also helpful for showing how the institutional context may matter for the degree of bricolage, that is, whether the bricolage is 'limited' or 'expansive'. As shown below, the autonomy enjoyed by Danish civil servants, along with a strong tradition for corporatist solutions to bank crises, was instrumental for Danish policymakers in building a resolution authority on the existing logic of action for resolving banks, while the Obama administration was pressured into incorporating institutional elements from another logic of action. Although further theorization and testing of the role of institutional context for bricolage during crisis is needed, the comparison of the American and Danish cases thus provides a first insight to how bricolage as a causal mechanism varies according to institutional context. 


\section{Special bank resolution policies in the United States and Denmark}

Central to post-crisis regulatory ambitions has been to create policies that give public authorities enhanced powers to intervene and resolve failing financial institutions, in regulatory lingo called 'special bank resolution regimes' (SRRs) (Financial Stability Board, 2011). The basic idea behind SRRs is to avoid what are considered two suboptimal solutions to bank crises, namely disorderly bankruptcy or a bailout of creditors. Both approaches are problematic in their own right. Bailouts throw public money after failing financial institutions and create an increased incentive for financial institutions to grow bigger and bet on being saved by the state in a future crisis. Bankruptcy, on the other hand, wipes out shareholders and forces hair-cuts on creditors, but given that bankruptcy procedures work relatively slowly and do not take financial stability into consideration, there is significant risk of creating uncertainty and contagious disruptions in financial markets (Cihak and Nier, 2013; Howarth and Quaglia, 2013; Tarullo, 2013; Huertas, 2014).

In the Danish case, all banks were before the creation of the SRR policy covered by standard bankruptcy law, which however was seldom used, because Danish authorities had been able on an ad hoc basis to find healthy banks to merge failing banks with. In the American case there existed during the crisis a split between commercial banks and financial holding companies. While the former were covered by a special insolvency regime created for commercial banks following the Savings and Loans Crisis of the 1980s, financial holding companies had to be resolved through standard bankruptcy proceedings. Given that the institutions not covered by special resolution mechanisms were also often much larger and more complex than commercial banks, this created strong pressures to bail out these institutions during the crisis.

To judge whether the SRR-policies crafted in Denmark and the United States indeed do constitute gradual but significant change, we need to know which other possibilities were realistically available to decision makers at the time (see Capoccia and Kelemen, 2007: 356). Three potential outcomes stand out. First, we may imagine an instance of basic continuity despite crisis, what Streeck and Thelen (2005) refer to as 'survival and return' of the institutional logic of action. In the American context this would entail that resolution of investment banks and financial holding companies would remain within the standard bankruptcy code with change likely amounting to incremental adjustments of existing bankruptcy law, perhaps giving authorities increased discretion in crafting flexible resolution of financial institutions. As we shall see below, this indeed was the solution first proposed by the Obama administration. In the Danish context, continuity would likewise entail that banks remain subject to standard bankruptcy legislation with the state as a mediator in supporting $a d$ hoc acquisitions of failing banks by healthy banks, a model developed through the banking crisis of the 1980s.

At the other end of Streeck and Thelen's scale, we find abrupt institutional breakdown and replacement, what is considered the terrain of traditional 
punctuated equilibrium models. One way to arrive at this result would be if the SRRs were accompanied by structural reforms of the financial industry, primarily the largest banks. Such, more radical, approaches could, for example, entail placing limits on the size of banks or imposing firewalls between retail deposits and other liabilities of banks, in both cases mandating the break up of large financial institutions. Although structural reform is not as such part of the set of SRR-policies, it carries the potential of making resolution a more credible option for the authorities in managing a large scale banking crisis, and thus also of the relevant actors - for example, creditors, shareholders, management, authorities - to change their strategic calculus and behavior. To be sure, in the United States, the Dodd-Frank Act did contain moves in direction of structural reform, most notably the so-called Volcker Rule that, in its original form, entailed restrictions on deposittaking banks from engaging in proprietary trading, that is, trading from their own accounts. However, by now there is generally a consensus that following vehement attacks from financial industry lobbyists, these rules do not have the bite or purity that its primary proponent, former Chairman of the Federal Reserve, Paul Volcker, had envisaged (see e.g. Cassidy, 2010; Taibbi, 2012).

Finally, we find the gradual transformations that Streeck and Thelen (2005) propose to study as long-term change processes. As argued below, the SRRs found in Denmark and the United States constitute such a change, although, in contrast to the processes of change analyzed by Streeck and Thelen (2005) and Mahoney and Thelen (2010), the changes happened relatively rapidly during a moment of intense crisis and not over an extended stretch of time. On one hand, the SRRs are actual institutional innovations that have significant consequences for how creditors are treated in bankruptcy and enable the state to intervene more forcefully by granting officials increased discretion in future banking crises (Howarth and Quaglia, 2013; Donnelly, 2014). On the other hand, the SRRs do not entail structural reforms of the respective banking sectors. Moreover, the policies are in large part institutionalizations of practices related to bank closures that were in use before the crisis. In that perspective, the SRRs do not entail a fundamental shift in logic of action, but are instead implemented to shore up the existing institutional setup while granting supervisors increased authority to intervene in failing banks.

\section{Institutional bricolage and the Danish SRR}

The Danish resolution regime - presented in June 2010 as an exit from the 2-year state guarantee on Danish banks created in October 2008 (see Østrup, 2010) - was radical for its time. Being a first post-crisis experiment in not bailing out creditors in case of bank failure (The Economist, 2011), it was designed - as the only scheme in Europe at that time - to ensure senior bondholders suffer losses, when a bank is unwound. The scheme was constructed so that if a bank chooses to be resolved under the scheme, a subsidiary company is established under the state-run liquidation company, Financial Stability Company (Finansiel Stabilitet), that takes 
ownership of assets and some liabilities, wiping out shareholders and making senior bondholders accept a write-down on their investment, and with resolution costs paid collectively by the Danish banking sector (see Ministry of Economic and Business Affairs, 2010). With its relatively aggressive approach to creditors, the Danish SRR ended up amounting to a significant and yet gradual change in the logic of action behind bank resolution.

Before the crisis hit in 2007, there was already a well tested - although, in formal terms - weakly institutionalized resolution approach in place. It had been developed by Danish authorities during the banking crisis of the late 1980s, where between 1984 and 1994 a total of 47 destitute financial institutions were either unwound or merged with other more healthy institutions. In the majority of these cases, the crises were solved without public support. Generally the authorities employed a more or less improvised strategy of quick mergers between distressed and healthy banks and, when deemed necessary, public guarantees for specific institutions were issued. The handling of the crisis at the end of the 1980s has generally been regarded as successful by the authorities (Ministry of Economic and Business Affairs, 1997). Thus, before the implementation of the Danish SRR of 2010, the state played an active, albeit more informal, role in bank closures. It did so by letting the Danish central bank foster private solutions for banks in trouble, by putting pressure on other healthier banks to buy up failing banks and by offering considerable tax deductions to incentivize acquisitions.

These principles were expressed through the institutional setup in place before the crisis hit. Most important in this regard was the privately funded but publicly regulated Deposit Guarantee Fund (Indskydergarantifonden). The fund was reformed in 1994 to enable it to offer guarantees to help a smooth transition of ownership in cases of bank collapse, but because these measures turned out to conflict with EU legislation regarding state subsidies, in 2007 the banking sector collectively created the Private Contingency Association. The aim of the association is to support the takeover of distressed banks by stronger competitors, for example by issuing guarantees on some of the assets acquired. The association was a continuation of the facility under the deposit guarantee scheme, which could assist members in covering extraordinary charges in relation to takeovers or mergers in distressed institutions (Kluth and Lynggaard, 2013). The association can thus be viewed as an integrated part of solving banking crises in Denmark and constitutes the institutionalization of an old tradition of cooperation between banking sector and state in Danish banking crises. When Danish policymakers approached the question of how to handle failing banks during the recent financial crisis, they thus did so from two basic principles that were fostered during the previous banking crisis, specifically, first, a principle of industry rather than public funding of resolution, and, second, a principle of avoiding state ownership (Iversen, 2013: 203). Though these principles were the starting point, they needed reinterpretation and redeployment under new circumstances of intense international pressure on Danish banks. 
At first, however, the authorities sought to uphold the model for unwinding distressed banks that was developed in the last bank crisis, that is, posing guarantees to specific institutions, letting other healthier banks take over the distressed banks and upholding a strict non-state ownership policy. That worked in the case of the small bankTrelleborg that failed in the beginning of 2008 and was subsequently bought by the much larger Sydbank. However, this model for handling crises already had to be given up in its purest form, when in the Spring of 2008, the eighth largest lender in Denmark, Roskilde Bank, got into trouble. At first the Danish central bank tried to sell the bank but, with a roaring international crisis, no one showed interest and so the bank was dismantled with a state guarantee. The handling of the crisis turned out to be very expensive for the state. In the agreement for a state guarantee for Roskilde Bank between the financial sector and the state, the financial sector only had to pay 750 million $\mathrm{DKr}(\sim € 100$ million), and the state was left to pay just over 10 billion $\mathrm{DKr}$ ( €1.3 billion) unwinding the bank.

With the recognition on part of the authorities that it was not realistic to expect large Danish banks to buy up failing banks - as had been the practice in the previous banking crisis - a new approach was gradually developed. One particularly important bank failure was the case of Fionia Bank. When the bank was showing clear signs of failure in February 2009, the authorities - contrary to the normal procedure of merging with a healthy bank - chose to inject 1 billion DKr ( €134 million) into the bank to ensure its solvency. In what constituted a new interpretation of the principle that the state should not take ownership in failing banks, the authorities - using a bridge bank model where healthy and toxic elements were split - spent the following half year finding an institution willing to buy the healthy parts of the bank (Iversen, 2013:114). In the end, the healthy parts of the bank were bought by the second largest bank in Denmark, Nordea, while toxic assets were resolved by Financial Stability as part of the state guarantee.

These initial experiences mattered for how Danish policymakers ended up interpreting the principle of industry funded resolution and the principle of no state ownership of banks. Thus, much similar to the model developed for the Fionia Bank resolution, the SRR policy that was presented in June 2010 enabled Danish authorities to transfer assets and some liabilities (like insured deposits) from the failing bank to a bridge bank and let Financial Stability pay off depositors and sell off the assets in an orderly fashion. This, importantly, meant that creditors were not fully covered - popularly speaking, they would not be bailed out - and any additional resolution costs would be covered by the banking sector, in turn relieving the taxpayers of the bill for resolving a failing bank. Taken together, the Danish SRR was different from previous practices of bank resolution - specifically in how active a role the state would take in the resolution process through its use of a bridge bank mechanism - and the redeployment of existing institutional principles thus amounted to an instance of institutional bricolage as laid out above.

It is worth noting that the bricolage did not only occur in the initial creation of the SRR, it was also the mode of policymaking employed by politicians and civil 
servants, when significant adverse effects of the SRR policy on the Danish banking sector's competitiveness had been acknowledged. Thus, following the realization that the Danish SRR policy was too aggressive at that point of the crisis - Danish banks were basically shut out from international money markets when the SRR was used on Amagerbanken and Fjordbank Mors resulting in hair-cuts on creditors - a new, amended policy was passed in agreement between opposition and government. The aim of the new scheme was to subsidize takeovers in an effort to avoid troubled banks being forced to resort to the new resolution framework. The bill opened the possibility that a healthy bank could take over either the whole of the distressed bank or only buy the good parts and leave toxic assets to the state. Importantly, transactions would be subsidized by the Deposit Guarantee Fund, which, as noted already, is financed collectively by the Danish banking sector.

This approach yet again redeployed an institution originally hatched long before the crisis. Although mergers were actively sought by the authorities in the banking crisis of the 1980s, resolution was accomplished without directly subsidizing the consolidation process, because it was possible to find interested buyers among the healthier banks. As mentioned above, this was also the approach of policymakers in the beginning of the crisis and the basis for the Danish SRR policy, but with the amended SRR scheme - which was created to alleviate the consequences that followed from the use of the original SRR model - the authorities enabled the provision of a dowry to help healthy banks take over failing banks. The scheme offered two options for supporting the take over of a failing bank: either a viable bank takes over an entire distressed bank (except share capital and other subordinated capital) with a dowry, or the state takes over a distressed bank, sells the healthy assets to a bank and receives a dowry to fund the resolution of the remaining assets. In both models, the dowry is financed by the Deposit Guarantee Fund, which is funded by the banking sector. The dowry scheme constitutes a formalization and strengthening of a practice of actively supporting takeovers using tax deductions and guarantees. As argued by Hansen (1997), there has long existed a strong political wish in Denmark that collapsing banks should be merged with healthy institutions to avoid an expensive and unpractical collapse, and an important supporting mechanism has been the tax deductions for the buying bank. The dowry scheme is thus a pragmatic but also more formal solution built on existing informal institutions from pre-crisis times. ${ }^{2}$

The analysis illustrates how in the Danish case the process of crafting an SRR policy was characterized by institutional bricolage. The Danish SRR thus

\footnotetext{
2 Although in principle the Danish SRR applied to all Danish financial institutions, it was clear that it would not be as easy to close down the largest banks - for example Danske Bank with assets amounting to $200 \%$ of Danish GDP - as it had been to close down small banks. The marked differences in funding costs for large and small banks also signified that the commitment to close down all banks using the new SRR was not deemed credible by creditors. The solution thus became to craft special capital and liquidity standards for so-called SIFIs, a policy that was decided on in October 2013.
} 
constituted a rearrangement of existing institutional and ideational elements that formed a more tightly institutionalized approach to handling banking crises. In the words of the framework set out above, the Danish SRR made up a limited bricolage, where the pre-crisis logic of action was applied under novel circumstances leading through a process of trial-and-error to a gradual change in the way the authorities approached bank resolution. The central elements of the SRR - including the role given to the financial sector in financing the scheme as well as the role of the Danish state in brokering deals and offering favorable conditions for takeovers - were thus extensions of pre-crisis institutions. Having existing institutions and principles as a starting point, the process behind the creation of a new institution for bank resolution in Denmark was characterized by improvisation. When the crisis broke out, the authorities tried first to simply convert existing approaches to new circumstances - specifically by letting the Danish central bank handle the crisis - but it quickly turned out to be necessary to create a new set of institutions. The new institutions were developed continually, first starting from the more informal template in the beginning of the crisis, to the institution of the Danish SRR through to the dowry scheme that was created to help stabilize the Danish banking sector by reopening access to funding markets.

\section{Institutional bricolage and the American SRR}

Considering that the recent financial crisis involved tremendous costs and significant disruption to institutions throughout US society, and that the onset of the crisis was followed closely by a national election in which the financial crisis was a central issue, the financial crisis offered great possibilities for large institutional change in financial regulation. And yet, much indicates that the changes brought on by the Dodd-Frank Wall Street and Consumer Act (in the following: the DoddFrank Act) are more incremental than revolutionary (Woolley and Ziegler, 2012: 29, see also Carpenter, 2011; Lavelle, 2013). Much the same can be said about the American SRR that was created as part of the Dodd-Frank Act. Although it clearly constitutes a significant policy change in the rules relating to crisis management in SIFIs, it is nonetheless best understood as a gradual shift, where new institutional elements are added to the existing approach to crisis management. Specifically, the American SRR policy is characterized by 'expansive bricolage', where the new institutional setup is based on a combination of (1) the existing logic of action developed in previous crises of financial institutions (i.e. public support for private resolution of crises), and (2) the logic of action of the adjacent field of bank crises, that is, the FDIC's handling of bank failures following a more rule-based and non-discretionary approach.

The American approach to resolution of financial institutions is contained in Title II of the Dodd-Frank Act, the 'Orderly Liquidation Authority'. The resolution approach works in a way where any financial institution deemed 'in default or in danger of default', where the failure of the institution would have 'serious adverse 
effects on financial stability in the United States' (Section 203b), is subject to resolution. The resolution process starts when the Treasury Secretary, two-thirds of the Board of Governors of the Federal Reserve System and two-thirds of the board of the FDIC vote to recommend the resolution of a financial institution (Section 203a). The Title II stipulates that the purpose of the Orderly Liquidation Authority is to provide the necessary authority to liquidate failing financial companies (as opposed to, e.g., reorganize them to bring them back to solvency) so that creditors and shareholders bear the losses of the financial company and management is held accountable (Section 204a), with any additional resolution costs shouldered post hoc by other SIFIs. As receiver, the FDIC is able to remove senior management and wipe out shareholders without the appointment of the court; manage the bankruptcy process, including asset sales and repayment of creditors; and conduct so-called purchase and assumption transactions where the FDIC lets another bank acquire the failing bank using a bridge bank tool that enables the FDIC to clean up the failed bank for bad assets (Marinc and Vlahu, 2012: 115). Section I of the Dodd-Frank Act also contains provisions relevant for resolution. One is the Early Remediation Requirements, where the Federal Reserve creates a set of standards for large financial institutions that if breached, requires that authorities take progressively more aggressive corrective action towards the financial institution beginning with heightened supervisory review and ending with resolution $(\$ 166 \mathrm{~b})$. In addition, Section 1 of the Dodd-Frank Act contains rules on resolution plans (popularly called 'living wills'), where financial institutions are required to submit plans that describe the company's strategy for rapid and orderly resolution under the U.S. Bankruptcy Code in the case of crisis.

This approach was different from what the Obama administration and Treasury had first outlined as its preferred approach to resolution. Thus, although the first proposal from the Obama administration on enhanced resolution authority over SIFIs sought to institutionalize and make more efficient the crisis management approach that had been practiced on an ad hoc basis during the crisis, the resolution approach of Dodd-Frank ended up containing important institutional elements from a different - less discretionary, more rule based - logic of action. Put differently, the American SRR developed from two logics of action the principles of which, to some extent, conflict.

On one hand, the American resolution approach represents the logic of action that has structured how crises in SIFIs have been dealt with before and during the recent crisis. Going back to the privately consorted bailout of the hedge fund LongTerm Capital Management in 1998, through the supported merger of Bear Stearns with JP Morgan Chase, to the nationalization of the government-sponsored mortgage institutions Fannie Mae and Freddie Mac during the recent crisis, there is a strong American tradition for ad hoc publically supported private crisis management. When Lehman's collapse became imminent, Paulson and Geithner sought to achieve a rescue along the lines the New York Federal Reserve had used with Long-Term Capital Management, where no governmental money would be 
used (Stewart, 2009; Lavelle, 2013), but what made the crisis of Lehman Brothers different was that the authorities were unable to find a bank willing to take over the failing institution, and without authority to take over Lehman Brothers, bankruptcy was the only option left (Paulson, 2010; Geithner, 2014).

It was the preference of the Obama administration and the Treasury that this logic of action should dominate the new set of SRR institutions, which is seen from how strongly it is represented in the Treasury's white paper on regulatory reform published in June 2009 (Treasury, 2009). This approach could be characterized as a 'limited bricolage' in that it sought to apply the existing logic of action to new circumstances. The Obama Administration, spearheaded by Treasury Secretary Timothy Geithner, thus started out by presenting a model for resolution that sought to formalize the resolution approach to failing SIFIs used before and during the crisis. According to the White Paper, 'The proposed resolution regime is modeled on the "systemic risk exception" contained within the existing FDIC resolution regime' (p. 77). This refers to the exception contained in FDICIA that allows the FDIC to depart from the least cost resolution standard (see below), when financial stability is at risk, which opens for more flexibility and discretion in the choice of resolution approach.

The allusion to the systemic exception gives the impression that the proposed resolution authority is expected to work in a way where it increases not only the ability of authorities to bypass bankruptcy proceedings but also the flexibility with which authorities can resolve financial institutions. This notion is given further support by the tools that the White Paper proposes to make available to Treasury, namely 'the ability to establish conservatorship or receivership for a failing firm' as well as the ability to 'stabilize a failing institution ... by providing loans to the firm, purchasing assets from the firm, guaranteeing liabilities of the firm, or making equity investments in the firm' (Treasury, 2009: 77). What is notable about these tools is the leeway they would provide for the authorities to not only liquidate a failing institutions but also to reorganize it.

Had the Obama Administration been able to get this model through the legislative process, the American case would have been a case of 'limited bricolage', where the existing logic of action had been adjusted to fit new circumstances. As it turned out, it was not possible to gain the necessary support for the approach outlined in the initial proposal. Rather, Congress wanted to write its own bill (Carpenter, 2011; Woolley and Ziegler, 2012), and politicians and regulators accused this first model for institutionalizing many of the tools that had been practiced in the bailouts of a number of large American financial institutions during the crisis. The political controversy turned on the abovementioned vocabulary of 'reorganization' and the use of 'different forms of financial assistance in order to stabilize the institution in question'. As noted by the then head of the FDIC, Sheila Bair - who was one of the policymakers who most forcefully promoted the idea that the existing FDIC-model should be used as the model for the Dodd-Frank resolution model - the approach developed by Treasury Secretary Timothy Geithner was a far cry from what the 
FDIC had hoped for: "Though it created new resolution tools that were "modeled" on the FDIC's, it also gave the government huge latitude to keep doing bailouts' (Bair, 2012: 183). This interpretation is supported by the subsequent argument of the chief architect of the Treasury's proposal, Timothy Geithner, that 'the biggest problem with Dodd-Frank is not enough emergency bailout authority' (Geithner, 2014: 432).

Although the starting point for the creation of the Dodd-Frank resolution approach was the logic of action already in place, for political reasons it turned out necessary to add institutional elements from a different logic of action, namely the resolution approach used by the FDIC on deposit insured banks following the provisions of the Federal Deposit Insurance Corporation Improvement Act (FDICIA) of 1991. As a reaction to the Savings and Loans Crisis of the 1980s and 1990 s - which is estimated to have cost taxpayers around $\$ 160$ billion - a separate bankruptcy code for banks was implemented with the passage of FDICIA. The aim of FDICIA was to limit agency discretion and regulatory forbearance, which policymakers in the Congress blamed for increasing losses to the desposit insurance fund and the failure of regulators to intervene during the Savings and Loans Crisis. FDICIA expanded the powers of the FDIC by giving it responsibility for resolving savings and loan associations and commercial banks, an authority that it, before the act, shared with other regulators.

FDICIA was based on a rejection of the logic of action that had permeated crisis management during the preceding decades. That is, while policymakers during the 1980s had increased agency discretion in providing assistance to failing banks most notably the Garn St-Germain Act (1982) that enhanced the powers of the FDIC to provide aid to troubled institutions - FDICIA marked a turn towards rulebased intervention and resolution that limited agency discretion and the possibility for forbearance, but did not entail large structural changes to the banking industry (Benston and Kaufman, 1994).

The resolution approach of FDICIA was based on the idea of structured early intervention and resolution (Benston and Kaufman, 1994), which served as inspiration to a number of the provisions of the Dodd-Frank resolution authority. One example is the Early Remediation Requirement of Dodd-Frank, which is based on the 'prompt corrective action' (PCA) provision of FDICIA. Before FDICIA, banking regulators were limited to taking over a bank in the narrow circumstances of regulator-defined insolvency (FDIC, 1997), but with the passing of FDICIA regulators' takeover powers were expanded to three broad grounds for entering a bank into receivership: insufficient capital, insolvency, and violations of laws or regulations. The basic aim was to avoid resolution of a failing institution at the point when net worth becomes negative. This was sought achieved through the PCA provisions of the act that required regulators to take a series of actions as a bank's financial condition deteriorates through five categories of capitalization, from well capitalized to critically undercapitalized (see FDIC, 2003). The rationale behind the PCA was, on the one hand, to impose the same strains on federally insured banks as 
market discipline would lead to, that is, automatic sanctions in case of falling bank performance (e.g. capital ratios) levels, and, on the other, to minimize agency discretion by replacing it with rules (Benston and Kaufman, 1994: 16). The introduction of the Early Remediation Requirements in Dodd-Frank similarly draws on a logic of action that seeks to limit agency discretion by establishing a series of specific remedial actions to be taken by a systemically important financial institution experiencing financial distress.

The skepticism towards agency discretion is also seen in another important part of the Dodd-Frank resolution policy, namely the requirement that all financial institutions that enter the resolution process must be liquidated. This provision was very different from the logic of action characteristic of the Treasury's first proposal for regulatory reform that opened the possibility of reorganization of a failing institution, that is, that authorities would be able to support an institution in a way that would bring it back to solvency. Faced with the critique that the new resolution authority really amounted to an institutionalization of bailouts - a critique coming primarily from Republicans and right-leaning commentators - in the end, the tools enabling authorities to reorganize were removed from the final bills of the House of Representatives (the Frank Bill, passed in December 2009) and the Senate (the Dodd Bill, passed in March 2010) proposal. Some flexibility is still left for the authorities, since they are allowed to move assets to a bridge bank to enable an orderly resolution, but liquidation is still the only option once a systemically important institution has entered the resolution process, bringing the resolution approach of Dodd-Frank closer to the logic of action represented by FDICIA.

\section{Conclusion}

How may we understand and conceptualize the occurrence of gradual change following an economic crisis? Spending most of their energy supporting the claim that gradual change may over time lead to significant transformation, the gradualists have largely left unexplored the question of how actors deal with more abrupt change processes. This is unfortunate, since the approach to institutional change developed by gradualist institutionalists like Streeck and Thelen (2005) is indeed relevant for understanding the change that occurred following the financial and economic crisis of 2007-10. In the spirit of recent efforts within historical institutionalism to make greater room for dynamics of change other than punctuated equilibriums or fundamental stability, this paper has offered the notion of institutional bricolage as a way forward in analyzing institutional change during the uncertainty of crisis. This paper suggests three reasons why the approach holds promise. First, with a continual interest among historical institutionalists in how critical junctures might or might not lead to significant institutional change, the importance of crises has never been in doubt, but what actually happens in these crises has remained somewhat murky. In this regard, the concept of institutional bricolage is helpful as an analytical category that captures both how existing structures limit the ability of actors to change the 
institutional setup as well as the potential for a creative redeployment of existing institutional entities that creates new institutions.

Second, the bricolage approach to institutional change offers a useful perspective on the question of why a period of prolonged crisis does not necessarily lead to either a paradigmatic shift or the survival and return of pre-crisis institutions. An understanding of institutional change through bricolage provides an additional possible outcome of such a process, namely that actors' reorganization of existing institutions in times of crises may lead to significant, albeit gradual, transformation. Thus, in zooming in on the policy process surrounding the establishment of the American and Danish models for resolving failing financial institutions, the two case studies show that despite the significance and novelty of the policies, they were created from existing institutional principles developed on the back of previous American and Danish banking crises, respectively. Thus, the creation of the American SRR fits well with Woolley and Ziegler's (2012) overall assessment of the Dodd-Frank Act as broadly 'preservationist' in nature, since it maintained most of the existing regulatory landscape by creating a new resolution mechanism from the institutions already in place for resolving smaller banks. In this way, it resembles the process and outcome of the policy developments behind the Danish SRR. Although certainly the Danish SRR was a significant policy shift, it was also an institutionalization of practices that had been taking place in the previous banking crisis. In both cases, then, policies were modeled on approaches developed earlier, and then applied to considerably different circumstances.

Third, the bricolage approach is helpful in emphasizing how processes of institution building are seldom a one-shot game, where a new regime is created in a clearly delimited period. Instead, policies often - and perhaps this is especially the case in periods of crisis - need continual development to answer to unforeseen consequences and developments. For example, in the Danish case, adaptations were necessary when it turned out that the policy was implemented so effectively that it adversely affected the competitiveness of Danish banks. Once again, policymakers drew on institutions and principles of crisis management that were originally developed before the crisis and then adjusted them to fit current circumstances. In the American case, the adaptations were more political in nature. Starting from a model of bank resolution that made skeptics argue that the new SRR was simply an institutionalization of bailouts, proponents of the SRR found it necessary to add, to their proposal, requirements that made bailouts less likely (in principle, impossible) to conduct. In sum, both polities saw policymakers rearrange existing ideas and institutions to fit the project at hand while continuously improvising and working through trial-and-error to answer to the political and economic challenges they were faced with.

\section{Acknowledgments}

Previous versions of this paper were presented at the Annual Meeting of the American Political Science Association, Chicago, 29 August-1 September 2013, the Early Career Seminar, Department of Business and Politics, Copenhagen Business 
School, 26 August 2013, and at the 21st International Conference of Europeanists, Council of European Studies, Washington, D C, 14-16 March 2014. Comments received in these settings are thankfully acknowledged. The author thanks Edward Ashbee, John L. Campbell, Lasse Folke Henriksen, Christian Lyhne Ibsen, Manuela Moschella, Vivien A. Schmidt, Amin Samman, Liam Stanley, and Eleni Tsingou for taking the time to comment on the paper. The author also thanks the three anonymous reviewers and the editors of European Political Science Review for their constructive feedback. The financial support received from a Carlsberg Fund postdoc scholarship is gratefully acknowledged.

\section{Financial Support}

The research was supported by a postdoc grant from the Carlsberg Foundation.

\section{References}

Bair, S. (2012), Bull by the Horns: Fighting to Save Main Street and Wall Street from Itself, New York, NY: Simon \& Schuster.

Baker, A. (2015), 'Varieties of economic crisis, varieties of ideational change: how and why financial regulation and macroeconomic policy differ', New Political Economy 20(3): 342-366.

Beckert, J. (1999), 'Agency, entrepreneurs, and institutional change: the role of strategic choice and institutionalized practices in organizations', Organization Studies 20(5): 777-799.

Benston, G.J. and G.G. Kaufman (1994), 'The intellectual history of the Federal Deposit Insurance Corporation Improvement Act of 1991', in G.G. Kaufman (ed.), Reforming Financial Institutions and Markets in the United States, Boston, Dordrecht, London: Kluwer Academic Publishers, pp. 1-17.

Bermeo, N. and J. Pontussen (2012), Coping with Crisis: Government Reactions to the Great Recession, New York, NY: Russell Sage Foundation.

Blyth, M. (2002), Great Transformations: Economic Ideas and Institutional Change in the Twentieth Century, Cambridge: Cambridge University Press.

— (2010), 'Ideas, uncertainty, and evolution', in D. Béland and R.H. Cox (eds), Ideas and Politics in Social Science Research, New York, NY: Oxford University Press, pp. 83-101.

Campbell, J.L. (2004), Institutional Change and Globalization, Princeton, NJ: Princeton University Press.

Capoccia, G. and R.D. Kelemen (2007), 'The study of critical junctures: theory, narrative, and counterfactuals in historical institutionalism', World Politics 59: 341-369.

Carpenter, D. (2011), 'The contest of lobbies and disciplines: financial politics and regulatory reform in the Obama administration', in L. Jacobs and T. Skocpol (eds), Reaching for a New Deal: Obama's Agenda and the Dynamics of U.S. Politics, New York, NY: Oxford University Press and Russell Sage Foundation, pp. 139-188.

Carstensen, M.B. (2011), 'Paradigm man vs. the bricoleur: an alternative vision of agency in ideational change', European Political Science Review 3(1): 147-167.

_ (2013), 'Projecting from a fiction: the case of financial crisis in Denmark', New Political Economy 18(4): 555-578.

- (2015), 'Bricolage as an analytical lens in new institutionalism', in F. Panizza and T. Spanakos (eds), Conceptual Comparative Politics, London: Routledge, pp. 46-67.

Cassidy, J. (2010), 'The Volcker Rule: Obama's economic adviser and his battles over the financial-reform bill'. The New Yorker, July 26, pp. 23-30, available at http://www.newyorker.com/reporting/2010/ 07/26/100726fa_fact_cassidy

Cihak, M. and E. Nier (2013), 'The need for special resolution regimes for financial institutions - the case of the European Union', Harvard Business Law Review 2(2): 395-434. 
Clift, B. (2012), 'Comparative capitalisms, ideational political economy and french post-Dirigiste responses to the global financial crisis', New Political Economy 17(5): 565-590.

Crouch, C. (2005), Capitalist Diversity and Change: Recombinant Governance and Institutional Entrepreneurs, Oxford: Oxford University Press.

Cyert, R. and J.G. March (1963), A Behavioral Theory of the Firm, Englewood Cliffs, NJ: Prentice Hall.

Deeg, R. (2005), 'Change from within: German and Italian finance in the 1990s', in W. Streeck and K. Thelen (eds), Beyond Continuity: Institutional Change in Advanced Political Economies, New York, NY: Oxford University Press, pp. 169-202.

Deeg, R. and G. Jackson (2012), 'The long-term trajectories of institutional change in European capitalism', Journal of European Public Policy 19(8): 1109-1125.

DiMaggio, P.J. and W.W. Powell (1983), 'The iron cage revisited: institutional isomorphism and collective rationality in organizational fields', American Sociological Review 48(2): 147-160.

Djelic, M.-L. and S. Quack (2007), 'Overcoming path dependencies - path generation in open systems', Theory and Society 36(2): 161-186.

Donnelly, S. (2014), 'Power politics and the undersupply of financial stability in Europe', Review of International Political Economy 21(4): 980-1005.

The Economist (2011), 'Small enough to fail'. The Economist, June 28, pp. 60-61. Retrieved 18 February 2015 from http://www.economist.com/blogs/freeexchange/2011/06/european-banks.

Etienne, J. and G. Schnyder (2014), 'Logics of action and models of capitalism', Swiss Political Science Review 20(3): 365-387.

FDIC (1997), History of the Eighties - Lessons for the Future, Vol. 1: An Examination of the Banking Crises of the 1980s and Early 1990s, Washington, DC: Federal Deposit Insurance Corporation.

FDIC (2003), Managing the Crisis: The FDIC and RTC Experience, Washington, DC: Federal Deposit Insurance Corporation.

Financial Stability Board (2011), Key Attributes of Effective Resolution Regimes for Financial Institutions, Basel: Financial Stability Board.

Geithner, T. (2014), Stress Test: Reflecting on Financial Crises, London: Random House Business Books.

Hansen, P.H. (1997), 'Bankredninger i Danmark - en stabil tradition', in T. Andersen and K. Ronit (eds), Den danske banksektor - mellem tradition og forandring, Aarhus: Systime, pp. 37-76.

Helleiner, E. (2014), The Status Quo Crisis: Global Financial Governance After the 2008 Meltdown, New York, NY: Oxford University Press.

Howarth, D. and L. Quaglia (2013), 'Banking union as holy grail: rebuilding the single market in financial services, stabilizing Europe's banks and 'completing' economic and monetary union', Journal of Common Market Studies 51(annual review): 103-123.

Huertas, T. (2014), Safe to Fail: How Resolution will Revolutionise Banking, Houndmills, Basingstoke: Palgrave MacMillan.

Iversen, M.J. (2013), Sidste udvej: Finansiel Stabilitet og Danmarks bankkrise, Copenhagen: Lindhardt og Ringhof.

Kluth, M. and K. Lynggaard (2013), 'Explaining policy responses to Danish and Irish banking failures during the financial crisis', West European Politics 36(4): 771-788.

Lavelle, K.C. (2013), Money and Banks in the American Political System, New York, NY: Cambridge University Press.

Levi-Strauss (1996 [1962]), The Savage Mind, Oxford: Oxford University Press.

Lindblom, C. (1959), 'The science of “muddling through"', Public Administration Review 19(2): 79-88.

Lustick, I. (1980), 'Explaining the variable utility of disjointed incrementalism: four propositions', American Political Science Review 7(2): 342-353.

Mahoney, J. and K. Thelen (2010), 'A theory of gradual institutional change', in J. Mahoney and K. Thelen (eds), Explaining Institutional Change: Ambiguity, Agency, and Power, New York, NY: Cambridge University Press, pp. 1-37.

March, J.G and H. Simon (1958), Organizations, New York: John Wiley.

Marinc, M. and R. Vlahu (2012), The Economics of Bank Bankruptcy Law, Berlin, Heidelberg: Springer-Verlag. 
Ministry of Economic and Business Affairs (1997), Håndtering af pengeinstitutkriser, Copenhagen: Ministry of Economic and Business Affairs.

- (2010), Resolution Scheme for Winding Up Banks After 30. September 2010, Copenhagen: Ministry of Economic and Business Affairs.

Moschella, M. and E. Tsingou (eds) (2013), Great Expectations, Small Transformations: Incremental Change in Financial Governance, Colchester: ECPR Press.

Østrup, F. (2010), Det finansielle system, Copenhagen: Thomson Reuters.

Paulson, H.M. (2010), On the Brink: Inside the Race to Stop the Collapse of the Global Financial System, New York: Business Plus.

Schmidt, V.A. (2009), 'Comparative institutional analysis', in T. Landman and N. Robinson (eds), Handbook of Comparative Politics, Thousand Oaks, CA: Sage, pp. 125-143.

Schmidt, V.A. and M. Thatcher (eds) (2013), Resilient Liberalism in Europe's Political Economy, Cambridge: Cambridge University Press.

Schneiberg, M. (2007), 'What's on the path? Path dependence, organizational diversity and the problem of institutional change in the US Economy, 1900-1950', Socio-Economic Review 5: 47-80.

Skowronek, S. (1982), Building a New American State: The Expansion of National Administrative Capacities, 1877-1920, Cambridge: Cambridge University Press.

Soifer, H.D. (2012), 'The causal logic of critical junctures', Comparative Political Studies 45(12): 1572-1597.

Stewart, J.B. (2009), 'Eight days'. The New Yorker, September 21, pp. 58-81.

Streeck, W. and K. Thelen (2005), 'Introduction: institutional change in advanced political economies', in W. Streeck and K. Thelen (eds), Beyond Continuity: Institutional Change in Advanced Political Economies, New York, NY: Oxford University Press, pp. 1-39.

Taibbi, M. (2012), 'The slow, painful death of Dodd-Frank'. Rolling Stone, May 24, pp. 62-87.

Tarullo, D.K. (2013), 'Toward building a more effective resolution regime: progress and challenges'. Speech at the Federal Reserve Board and Federal Reserve Bank of Richmond Conference 'Planning for the Orderly Resolution of a Global Systemically Important Bank', October 18, Washington, DC.

Treasury (2009), Financial Regulatory Reform. A New Foundation: Rebuilding Financial Supervision and Regulation, Washington, DC: Department of the Treasury.

Woolley, J.T. and J.N. Ziegler (2012), 'The two-tiered politics of financial reform in the United States', in R. Mayntz (ed.), Institutional Change in the Regulation of Financial Markets, Cologne: Max Planck Institute for the Study of Societies, pp. 27-63. 